\title{
Rancang Bangun Aplikasi Pengelolaan Zakat, Infaq dan Sadaqah Pada Yayasan Al-Fatwa
}

\author{
Zulkarnain $^{\mathrm{a} 1}$, Helfi Nasution ${ }^{\mathrm{a} 2}$, M.Azhar Irwansyah ${ }^{\mathrm{a} 3}$ \\ ${ }^{a}$ Program Studi Informatika, Fakultas Teknik, Universitas Tanjungpura \\ Jl. Prof. Dr. H. Hadari Nawawi, Pontianak 78124 \\ ${ }^{1}$ zizou.lk.08@gmail.com \\ ${ }^{2}$ helfi nasutioneyahoo.com \\ 3irwansyah.azhar@gmail.com
}

\begin{abstract}
Abstrak
Perkembangan teknologi informasi mendorong setiap lembaga atau instansi untuk memperbaiki aplikasi dalam pekerjaannya, salah satunya dengan menggunakan suatu aplikasi berbasis komputer. Dukungan komputerisasi telah merambah disegala bidang, termasuk dalam proses pengelolaan zakat, infaq dan sadaqah (ZIS) pada Yayasan AlFatwa. Aplikasi diperlukan untuk proses penerimaan, pendataan orang yang berhak menerima (mustahik) dan penyaluran meliputi permasalahan seperti pembuatan laporan dan perhitungan penyaluran asnab setiap jiwa. Proses penerimaan yang dilakukan oleh 10 pos penerimaan selama ini masih konvensional atau tanpa memanfaatkan jaringan internet, sehingga terlambatnya laporan yang mengakibatkan proses penyaluran juga terjadi keterlambatan. Laporan penerimaan digunakan untuk menentukan besaran jumlah uang dan beras yang akan dibagikan kepada mustahik. Tujuan dari penelitian adalah menghasilkan aplikasi pengelolaan ZIS berbasis website sehingga dapat mendukung pada proses pengelolaan ZIS pada Yayasan Al-Fatwa. Metodologi penelitian yang dilakukan yaitu analisis kebutuhan, perancangan aplikasi, pembuatan aplikasi, pengujian dan penarikan kesimpulan. Metode pengembangan sistem menggunakan metode waterfall. Pengujian sistem dilakukan dengan dua cara, yaitu pengujian black box dan user acceptance test. Hasil pengujian black box adalah aplikasi dapat bekerja dengan baik dalam menangani suatu kemungkinan kesalahan, dan hasil dari pengujian user acceptance test dengan 5 orang responden dari 10 pertanyaan mendapat total skor 190 atau aplikasi dinilai positif dan cukup berhasil. Sehingga disimpulkan aplikasi dapat membantu petugas dalam pengelolaan zakat, infaq dan sadaqah pada Yayasan Al-Fatwa.
\end{abstract}

Kata kunci: Aplikasi ZIS, waterfall, Zakat, Infaq, Sadaqah

\section{Design Applications for the Management of Zakat, Infaq and Sadaqah at the Al-Fatwa Foundation}

\begin{abstract}
The development of information technology has encouraged every institution or agency to improve applications in its work, one of them by using a computer-based application. Computerized support has penetrated all fields, including in the process of managing zakat, infaq and sadaqah (ZIS) at the Al-Fatwa Foundation. Application is needed for the process of acceptance, data collection of people who are entitled to receive (mustahik) and distribution including issues such as making reports and calculating the distribution of each soul. The reception process carried out by 10 reception posts so far is still conventional or without utilizing the internet network, so that the delay in the report which results in the distribution process also occurs delays. The receipt report is used to determine the amount of money and rice that will be distributed to mustahik. The aim of the research is to produce a website-based ZIS management application so that it can support the ZIS management process at the Al-Fatwa Foundation. The research methodology used is the needs analysis, application design, application development, testing and drawing conclusions. The system development method uses the waterfall method. System testing is done in two ways, namely black box testing and user acceptance tests. The result of black box testing is that the application can work well in handling a possible error, and the results of the user acceptance test with 5 respondents out of 10 questions get a total score of 190 or the application is considered positive and quite successful. So it was concluded that the application can assist officers in managing zakat, infaq and sadaqah at the Al-Fatwa Foundation.
\end{abstract}

Keywords: ZIS application, Waterfall, Zakat, Infaq, Sadaqah 


\section{PENDAhuluan}

Data dan informasi adalah sesuatu yang sangat penting dan berharga dalam sebuah organisasi dewasa ini. Pengelolaan data dan informasi yang akurat dan cepat dapat membantu tumbuh kembang sebuah organisasi. Maka dari itu, pengelolaan data dan informasi dipandang penting demi kelancaran sebuah pekerjaan dan untuk menganalisa perkembangan dari pekerjaan itu sendiri. Untuk pengelolaan data dan informasi dibutuhkan sebuah sistem aplikasi terkomputerisasi. Sehingga dengan sistem aplikasi yang telah terkomputerisasi dan ditunjang dengan program aplikasi yang sesuai dengan kebutuhan akan dapat mengelola data-data yang lebih cepat dan akurat dibandingkan sistem sebelumnya. Menurut Jogiyanto aplikasi adalah penggunaan dalam suatu komputer, instruksi (instruction) atau pernyataan (statement) yang disusun sedemikian rupa sehingga komputer dapat memproses input menjadi output. Jogiyanto menambahkan aplikasi secara umum adalah suatu proses dari cara manual yang ditransformasikan ke komputer dengan membuat sistem atau program agar data diolah lebih berdaya guna secara optimal [1]. Aplikasi tersebut akan lebih praktis dan menawarkan kemudahan dari segi akses informasi. Pengembangan dalam teknologi informasi yang diterapkan dalam perusahaan maupun instansi bertujuan memberikan kelancaran dalam pengolahan data dan penyajian data. Kemudian hal tersebut akan menunjang penyediaan informasi bagi pihak luar instansi, serta memberi kemudahan sehingga diharapkan nantinya mempermudah dan mempercepat proses pelayanan penyimpanan data,serta penyajian kembali data tersebut.

Yayasan Al-Fatwa merupakan lembaga sosial kemasyarakat yang berada di Kecamatan Sungai Raya dengan salah satu program kerjanya ialah menghimpun dan menyalurkan zakat, infaq dan sadaqah, yang setelah ini akan disebut ZIS. Program kerja ini dilaksanakan selama 20 hari pada bulan Ramadhan dengan melakukan kegiatan penerimaan, pendataan mustahik dan penyaluran. Untuk proses penerimaan ZIS dilaksanakan oleh 9 pos yang berpusat di Masjid Besar Al-Fatwa. Ditengah masa penerimaan, dilakukan pendataan mustahik oleh petugas yang telah dibagi dalam 13 wilayah kerja. Yang terakhir, kegiatan penyaluran ZIS dilaksanakan pada hari terakhir di bulan Ramadhan.

Selama ini sistem pengelolaan ZIS menggunakan aplikasi pengolahan kata (word) dan aplikasi pengolahan angka (excel) untuk pengolahan data. Pada penerimaan sistem belum terintegrasi sehingga mengakibatkan terlambatnya penyaluran kepada mustahik dikarenakan laporan penerimaan terlambat dilaporkan oleh pos-pos penerimaan. Laporan penerimaan tersebut digunakan untuk perhitungan besaran jumlah penyaluran uang dan beras kepada mustahik perjiwa. Perhitungan yang dilakukan masih secara manual sehingga uang dan beras tidak habis disalurkan karena bersamaan dengan penyaluran, penerimaan ZIS masih berlangsung di pos penerimaan pusat. Akibatnya, petugas harus menyalurkan kembali sisanya dengan mendatangi mustahik satu persatu.
Dukungan suatu aplikasi diperlukan khususnya pengelolaan zakat, infaq dan sadaqah agar dapat membantu proses kegiatan di Yayasan Al-Fatwa. Aplikasi pengelolaan ZIS membantu kegiatan penerimaan, pendataan mustahik, penyaluran dan pelaporan serta membantu melakukan perhitungan jumlah penyaluran kepada mustahik.

Penelitian ini menjadi penting karena dapat mendukung pengelolaan ZIS yang terintegrasi. Berdasarkan latar belakang yang diuraikan maka perlu dirancang dan dibangun sebuah Aplikasi Pengelolaan Zakat, Infaq dan Sadaqah, untuk menunjang efektifitas kerja dalam berbagi informasi dan pengolahan data di Yayasan Al-Fatwa.

\section{Metodologi Penelitian}

\section{A. Penelitian Terkait}

Penelitian tentang aplikasi pengelolaan zakat, infaq dan sadaqah bukanlah hal yang baru dilakukan, beberapa penelitian sejenis mengenai pengelolaan zakat, infaq dan sadaqah telah dilakukan sebelumnya.

Ganda Yoga Swara dan Dasman Hakim melakukan penelitian dengan judul "Perancangan Sistem Aplikasi Pengolahan Zakat Berbasis Web (Studi Kasus: Badan Amil Zakat Masjid Raya Andalas Kota Padang). Penelitian ini membangun system untuk menyediakan fasilitas bagi administrasi (bagian pengolahan) untuk menginputkan data-data, melakukan perubahan data dan menghapus data-data diinputkan. Terdapat juga fitur laporan untuk pengguna dan fasilitas kalkulator zakat untuk zakat harta dan zakat profesi[2].

Amirizal, Fakultas Sains dan Teknologi Universitas Islam Negeri Sultan Syarif Kasim Riau, Tahun 2014. Membuat aplikasi Sistem Informasi Badan Amil Zaka Berbasis Web Kota Pekan Baru. Sistem Informasi Badan Amil Zakat merupakan sistem online yang digunakan untuk mengelola, mengatur dan membantu proses layanan serta dapat memberikan informasi kepada pengguna yang dapat diakses di jaringan internet. Sistem ini akan digunakan oleh admin, Baznas dan pimpinan system informasi ini lebih berfokus pada penyimpanan data daerah penyaluran zakat, data pengaduan kegiatan zakat, data masyarakat yang berhak menerima zakat (mustahik) serta pembuatan laporan perbulan dan pertahun untuk bahan dokumentasi oleh Badan Amil Zakat kota Pekan Baru [3].

Adhitya Kukuh Pribadi, Bayu Waspodo, dan Nur Aeni Hidayah melakukan penelitian dengan judul "Sistem Informasi penerimaan dan Penyaluran Zakat dengan distribusi Konsumtif dan Produktif. Perancangan aplikasi ini menggunakan tools use case sebagai metode bisnisnya dan database management system sebagai rancangan database-nya. Pengembangan sistem dengan Rapid Application Development sehingga aplikasi ini berorientasi objek. Aplikasi ini terhubung dengan jaringan intranet untuk memudahkan user dalam mengakses. Data muzaki terintegrasi dengan pengelolaan penyaluran zakat. Pihak manajemen juga dapat memperoleh informasi dari fitur-fitur laporan yang disajikan[4]. 
Berdasarkan beberapa penelitian tersebut, penelitian yang akan dilalukan yaitu berfokus pada aplikasi pengelolaan zakat fitrah, zakat maal, infaq dan sadaqah pada Yayasan Al-Fatwa yang berbasis Website. Tujuan dari penelitian ini adalah menghasilkan aplikasi pengelolaan zakat, infaq dan sadaqah guna memudahkan kinerja petugas dalam melakukan pengelolaan zakat, infaq dan sadaqah pada Yayasan Al-Fatwa.

\section{B. Metode Penelitian}

Dalam penelitian ini dilakukan suatu proses yang dilakukan secara ilmiah untuk keperluan sebuah penelitian. Metode tersebut digunakan untuk melakukan pemprograman aplikasi melalui kode program (source code) yang sesuai dengan kebutuhan aplikasi. Langkah Penelitian ini dapat di lihat pada gambar 1.

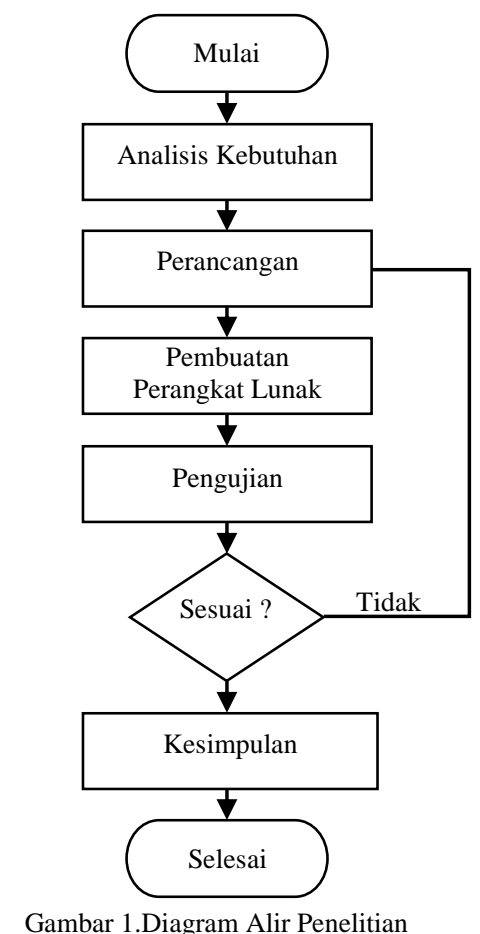

Berikut adalah penjelasan dari tahapan penelitan pada Gambar 1:

\section{1) Analisis Kebutuhan}

Analisis kebutuhan merupakan tahapan menganalisa dan memahami kebutuhan pada penelitian yang sedang dilakukan. Pada tahap awal yang akan dilakukan adalah mengidentifikasi kebutuhan sistem yang akan dibangun agar dapat berjalan semestinya.

\section{2) Perancangan}

Perancangan dilakukan berdasarkan analisis kebutuhan yang telah dilakukan. Ada beberapa tahapan yang dilakukan dalam perancangan aplikasi yaitu perancangan flowchart, arsitektur aplikasi, perancangan diagram DFD, spesifikasi basis data, perancangan antarmuka aplikasi dan perancangan pengujian.

\section{3) Pembuatan Perangkat Lunak}

Tahap ini akan dilakukan pembuatan aplikasi berdasarkan analisis kebutuhan dan perancangan aplikasi yang telah dilakukan pada tahapan sebelumnya. Hasil dari tahapan ini adalah suatu sistem pengolahan data yang sudah dapat berjalan dengan baik berhubungan dengan aplikasi.

\section{4) Pengujian}

Pengujian dilakukan dengan menggunakan metode black box dan User Acceptance Test.

Analisis hasil pengujian dilakukan untuk mengetahui apakah aplikasi yang dibuat telah menghasilkan hasil yang sesuai dengan perancangan yang sudah di tentukan. Pada hasil analisis pengujian dapat digunakan sebagai dasar penarikan kesimpulan.

\section{5) Penarikan Kesimpulan}

Penarikan kesimpulan merupakan tahapan akhir setelah analisa hasil pengujian yang telah dilakukan apakah aplikasi dapat diterima dan digunakan.

\section{Zakat, Infaq dan Sadaqah}

Zakat bisa didefinikan sebagai ibadah dijalan Allah yang berbentuk harta finansial dimana zakat itu termasuk kewajiban agama dan menempati posisi sebagai salah satu dari rukun islam [5]. Zakat terdiri dari zakat fitrah dan zakat mal. Menurut Abdul Bakir zakat fitrah adalah salah satu bentuk zakat yang diwajibkan untuk laki-laki, wanita, besar, kecil, anak-anak, dewasa dari umat ini yang waktunya sudah ditentukan yaitu sebelum Tanggal 1 Syawal. Jenis zakat yang dibayarkan berupa makanan pokok penduduk setempat yang bentuknya adalah bahan mentah yang belum dimasak dengan ukuran pada umumnya $2,5 \mathrm{Kg}$ perjiwa. Dalam prakteknya ada juga yang berzakat dengan menggunakan uang yang senilai dengan makanan pokok itu. Sedangkan zakat mal mempunyai beberapa sumber yaitu hasil pertanian, binatang ternak, emas dan perak, hasil perniagaan, hasil tambang, barang temuan dan zakat perusahaan. Orang yang membayar zakat disebut muzakki. Zakat mempunyai kedudukan yang penting, di Al-Qur'an ditegaskan kelompok-kelompok yang berhak menerima zakat biasa disebut mashraf atau masharif. Di Indonesia, umumnya istilah ini lebih dikenal dengan istilah mustahik, yang artinya orang-orang yang berhak. Mustahik terdiri dari delapan golongan atau asnab yaitu, fakir, miskin, amil zakat (pengelola zakat), mu'alaf, riqab, gharim, fisabilillah, dan ibnu sabil.

Infaq menurut Abdul Bakir adalah membayar dengan harta, mengeluarkan harta dan membelanjakan harta. Tujuannya bisa untuk kebaikan, donasi, aatau sesuatu yang bersifat untuk diri sendiri atau bahkan keinginan dan kebutuhan yang bersifat konsumtif. Sedangkan Sadaqah adalah membelanjakan harta atau mengeluarkan dana untuk tujuan mendekatkan diri kepada Allah yaitu maksudnya adalah ibadah atau amal shalih.

Didalam penyaluran zakat menurut Abdul Bakir masing masing asnab mendapat $1 / 8$ bagian dari total harta zakat. Namun karena syariat zakat itu punya esensi utama 
memberi harta kepada fakir miskin, maka hak yang diberikan kepada fakir miskin memang istimewa. Kalau harta itu masih belum mencukupi hak-hak fakir miskin, maka asnab yang lain harus dikalahkan demi kepentingan fakir miskin. Pada zakat fitrah memiliki banyak perbedaan kriteria dibandingkan dengan zakat harta, khususnya dalam masalah peruntukannya. Zakat fitrah ini dikhususkan hanya untuk fakir dan miskin saja, tanpa disebutkan pihak-pihak lain yang delapan asnab itu.

Pada Yayasan Al-Fatwa asnab fakir dan miskin digabungkan menjadi fakir miskin. Berdasarkan hal tersebut aplikasi ini akan menghitung pembagian fakir miskin sebesar $100 \%$ dari zakat fitrah dan 2/8 bagian dari zakat mal, infaq dan sadaqah. Jika tidak terdapat asnab lainnya, maka pembagian sebesar $1 / 8$ asnab tersebut dibagikan untuk fakir miskin.

\section{Metode Pengembangan Sistem}

Metode pengembangan sistem pada penelitian ini adalah dengan metode waterfall. Menurut Roger S. Pressman metode Waterfall merupakan model pengembangan sistem sistematis dan sekuensial. Tahapantahapan pengembangan sistem pada metode waterfall yaitu analisis, perancangan, implementasi, pengujian, dan pemeliharaan.

\section{E. Alat Bantu Perancangan Sistem}

Perancangan dilakukan dengan membuat konsep perancangan berupa rancangan awal aplikasi yaitu dengan Flowchart, Data Flow Diagram dan Entity Relationship Diagram (ERD).

Flowchart merupakan bagan (chart) yang menunjukan alir (flow) didalam program atau prosedur sistem secara logika[1]. Bagan alir sistem dapat disebut juga bagan yang menunjukan arus pekerjaan secara keseluruhan dari sistem dan bagan ini menjelaskan urut-urutan dari prosedurprosedur yang ada didalam sistem.

Data flow diagram (DFD) merupakan representasi grafik yang menggambarkan aliran informasi dan transformasi informasi yang diaplikasikan sebagai data yang mengalir dari masuk (input) sampai keluar (output)[6].

Entity Relationship Diagram (ERD) adalah suatu komponen-komponen himpunan entitas dan himpunan relasi yang masing-masing dilengkapi dengan atribut yang mempresentasikan seluruh fakta dari dunia nyata yang ditinjau[7].

\section{F. Basis Data}

Basis data merupakan kumpulan informasi bermanfaat yang diorganisasikan ke dalam aturan yang khusus[8]. Informasi ini adalah data yang telah diorganisasikan ke dalam bentuk yang sesuai dengan kebutuhan seseorang. Basis data sebagai kumpulan dari data yang saling berhubungan yang diorganisasi sedemikian rupa agar kemudian dapat dimanfaatkan lagi dengan cepat dan mudah[8].

Basis data yang digunakan pada sistem pendukung keputusan ini adalah MySQL. MySQL adalah salah satu perangkat lunak Sistem Manajemen Database (DBMS) yang sering digunakan saat ini, yang didistribusikan secara gratis dibawah lisensi GNU General Public License (GPL). MySQL menggunakan SQL sebagai bahasa dasar untuk mengakses database-nya[9].

Basis data sistem didalamnya terdapat hubungan antara entitas beserta relasinya. Perancangan database digambarkan dalam bentuk Entity Relationship Diagram (ERD).

\section{G. Pengujian Perangkat Lunak}

Pengujian perangkat lunak merupakan suatu teknik yang digunakan menguji apakah sebuah perangkat lunak yang dihasilkan telah sesuai dengan yang diharapkan atau belum. Menurut Pressman, pengujian adalah proses eksekusi suatu program untuk menemukan kesalahan sebelum digunakan oleh pengguna akhir (end-user)[10].

\section{H. Pengujian Black Box}

Metode uji coba blackbox memfokuskan pada keperluan fungsional dari software karena uji coba blackbox memungkinkan pengembang software untuk membuat himpunan kondisi input yang akan melatih seluruh syarat-syarat fungsional suatu program [10] .

Blackbox testing berusaha untuk menemukan kesalahan dalam kategori sebagai berikut:

1) Fungsi-fungsi yang tidak benar atau fungsi yang hilang

2) Kesalahan antarmuka (interface)

3) Kesalahan dalam struktur data atau akses database eksternal

4) Kesalahan perilaku (behavior) atau kesalahan kinerja

5) Inisialisasi dan pemutusan kesalahan.

\section{Pengujian Daya Terima}

User Acceptance Test merupakan pengujian yang dilakukan oleh end-user dimana user tersebut adalah karyawan perusahaan yang langsung berinteraksi dengan sistem dan dilakukan verifikasi apakah fungsi yang ada telah berjalan sesuai dengan kebutuhan/fungsinya[11]

Data yang diperoleh dari hasil pengujian kemudian diukur dengan metode Likert's Summated Rating (LSR). LSR yaitu skala yang digunakan untuk mengukur sikap, pendapat dan persepsi seseorang atau sekelompok tentang kejadian atau gejala[12].

1. Jumlah skor untuk setiap responden:

a. Skor maksimal $=5 \mathrm{x}$ jumlah item pertanyaan

b. Skor minimal $=1 \mathrm{x}$ jumlah item pertanyaan

c. Skor median $=3 \mathrm{x}$ jumlah item pertanyaan

d. Skor kuartil $\mathrm{I}=2 \mathrm{x}$ jumlah item pertanyaan

e. Skor kuartil III $=4 \times$ jumlah item pertanyaan

2. Jumlah skor untuk seluruh responden:

a. Maksimal $=$ skor maksimal $\mathrm{x}$ jumlah responden

b. Minimal $=$ skor minimal $\mathrm{x}$ jumlah responden

c. Median $=$ skor median $\mathrm{x}$ jumlah responden

d. Kuartil I = skor kuartil I x jumlah responden

e. Kuartil III = skor kuartil III x jumlah responden

3. Interpretasi jumlah skor tersebut adalah:

a. Kuartil III $<$ Skor $<$ Maksimal 
artinya sangat positif (program dinilai berhasil)

b. Median < Skor < Kuartil III artinya positif (program dinilai cukup berhasil)

c. Kuartil I $<$ Skor $<$ Median artinya negatif (program dinilai kurang berhasil)

d. Minimal < Skor < Kuartil I artinya sangat negatif (program dinilai tidak berhasil)

\section{J. Perancangan Arsitektur Aplikasi}

Arsitektur aplikasi merupakan cara yang digunakan untuk menggambarkan aplikasi secara umum, gambaran arsitektur tersebut dibangun berdasarkan informasi yang didapatkan dari wawancara serta yang berjalan saat ini. Komponen aplikasi terdiri dari data dan informasi atau proses, seperti pada Gambar 3, aplikasi yang akan dibangun ini berbasis web, yang dapat diakses oleh Yayasan Al-Fatwa yang terdiri dari super administrator, administrator, bagian penerimaan, bagian pendataan dan bagian penyaluran. Seluruh pengguna harus login terlebih dahulu agar dapat mengakses aplikasi. Super administrator dapat memasukkan data lembaga, pengelola administrator dan user administrator serta dapat melihat informasi pengelolaan ZIS seluruh lembaga. Administrator dapat mengelola master data yang terdiri dari pos penerimaan, wilayah pendataan, pengelola, users, dan menghitung jumlah penyaluran setiap asnab. Administrator juga dapat melihat laporan penerimaan, mustahik dan penyaluran. Bagian penerimaan dapat memasukkan data penerimaan ZIS. Bagian pendataan dapat memasukkan data mustahik. Bagian penyaluran dapat memasukkan data penyaluran ZIS kepada mustahik. Pimpinan harus login terlebih dahulu agar dapat melihat informasi dan hewan ternak tiap kecamatan. Admin kecamatan dapat memasukkan data populasi ternak dan melihat informasi populasi ternak. Sedangkan admin desa dapat memasukkan hasil laporan ternak setiap bulannya.

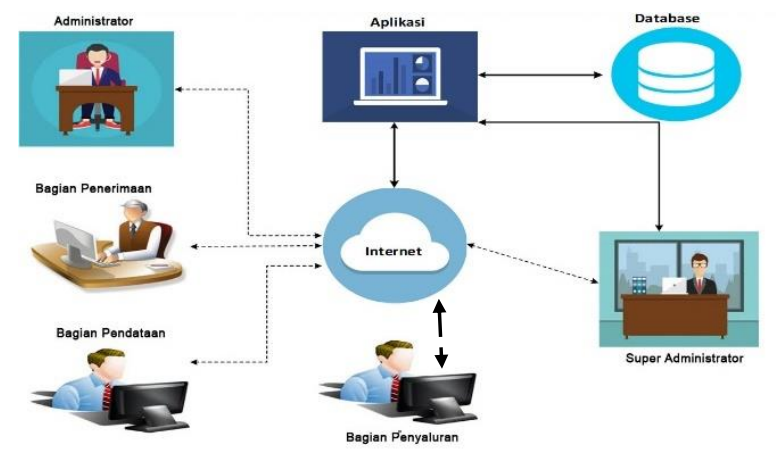

Gambar 2.Arsitektur Aplikasi ZIS

\section{K. Perancangan Antarmuka Aplikasi}

Perancangan antarmuka (interface) dirancang sebagai gambaran awal aplikasi yang akan dibangun. Perancangan antarmuka aplikasi meliputi beberapa pengguna diantaranya super administrator, administrator, bagian penerimaan, bagian pendataan dan bagian penyaluran. Berdasarkan struktur antarmuka seluruh pengguna akan ditampilkan halaman login untuk mengakses halaman utama aplikasi. Perancangan halaman login dapat dilihat pada Gambar 3.

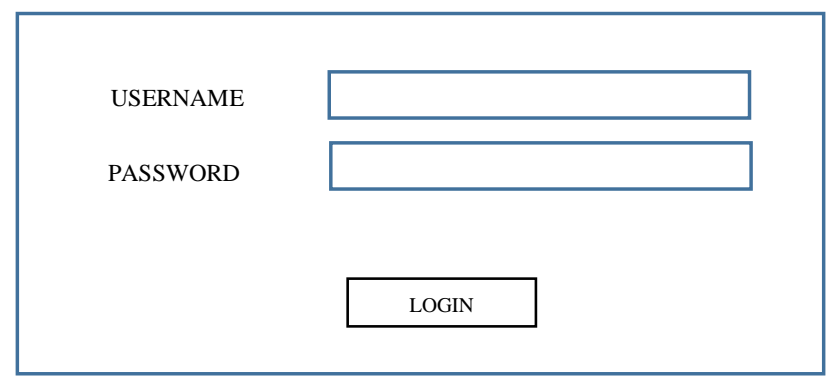

Gambar 3. Perancangan Halaman Login

Selanjutnya pengguna akan dapat mengakses halaman utama yang terdiri dari header, panel menu, keterangan, dan footer.

\section{HASIL DAN PENGUJIAN}

\section{A. Hasil Penelitian}

Perancangan yang telah dilakukan terdiri dari perancangan arsitektur aplikasi, diagram alir aplikasi, data flow diagram dan basis data. Perancangan tersebut menghasilkan sebuah Aplikasi pengelolaan zakat, infaq dan sadaqah. Antarmuka dari aplikasi diantaranya adalah antarmuka super administrator, antarmuka administrator, antarmuka bagian penerimaan, antarmuka bagian pendataan dan antarmuka bagian penyaluran.

\section{B. Antarmuka Halaman Login}

Antarmuka halaman login yaitu halaman yang diakses oleh pengguna. Pada halaman ini terdapat form login yang digunakan oleh pengguna ketika ingin menggunakan aplikasi. Tampilan halaman login dapat dilihat pada Gambar 4.

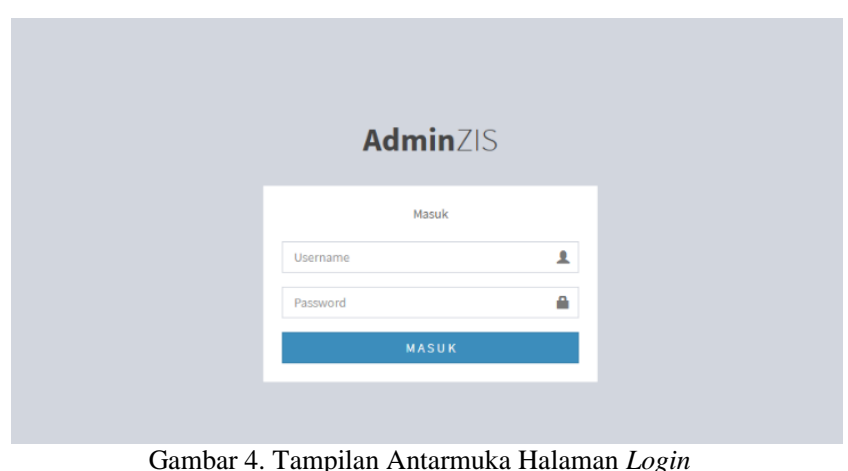

\section{Antarmuka Super Administrator}

Hasil perancangan antarmuka aplikasi salah satunya adalah antarmuka super administrator. Terdiri beberapa menu yaitu beranda, master data, dan laporan. Pada menu master data terdapat sub menu lembaga, pengelola dan users. Beranda merupakan menu utama setelah pengguna berhasil login. Pada halaman beranda ditampilkan informasi grafik penerimaan ZIS setiap tahun pengelolaan dan grafik mustahik setiap tahun pengelolaan. Tampilan halaman beranda dapat dilihat pada Gambar 5. 


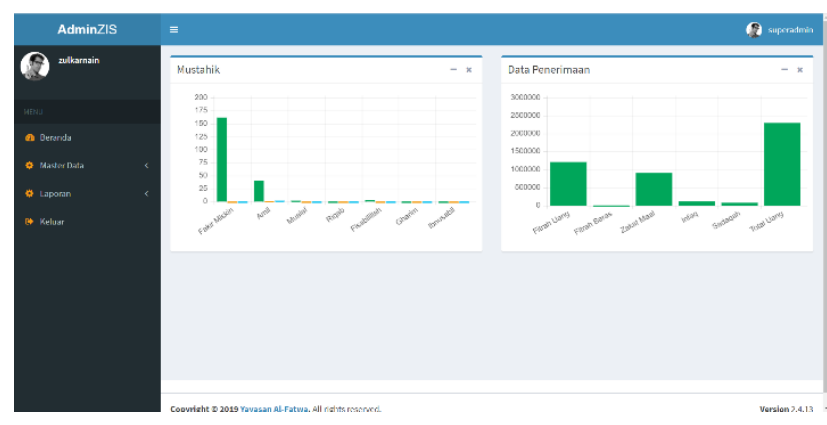

Gambar 5. Tampilan Antarmuka Halaman Menu Beranda

\section{Antarmuka Administrator}

Hasil perancangan antarmuka aplikasi salah satunya adalah antarmuka administrator. Terdiri beberapa menu yaitu Beranda, penerimaan, pendataan mustahik, penyaluran dan master data yang terdiri dari sub mеnu pengelola, pos penerimaan, wilayah pendataan, asnab dan users.

Beranda merupakan menu utama setelah pengguna berhasil login. Pada halaman ini ditampilkan informasi grafik mustahik dan penerimaan berdasarkan pos penerimaan. Selain itu terdapat juga ringkasan penerimaan dan penyaluran. Tampilan halaman menu Beranda administrator dapat dilihat pada Gambar 6.

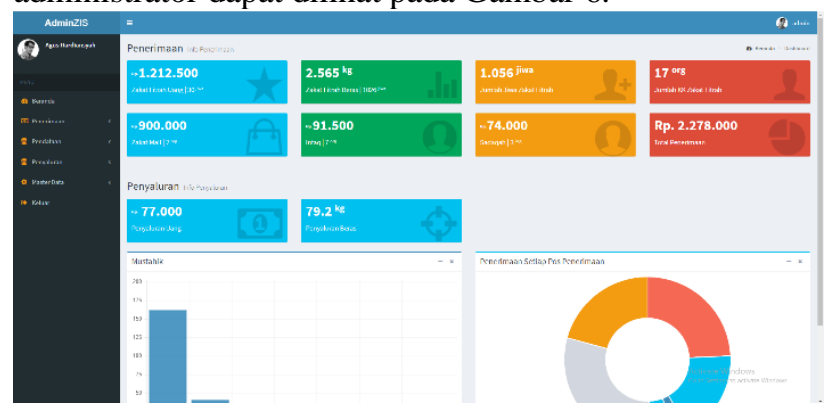

Gambar 6. Tampilan Antarmuka Halaman Menu Beranda

\section{E. Antarmuka Bagian Penerimaan}

Hasil perancangan antarmuka aplikasi salah satunya adalah antarmuka bagian penerimaan. Terdiri menu Beranda dan penerimaan.

Beranda merupakan menu utama setelah pengguna berhasil login. Pada halaman ini ditampilkan informasi seperti antar muka administrator. Tampilan halaman menu Beranda bagian penerimaan dapat dilihat pada Gambar 7 .

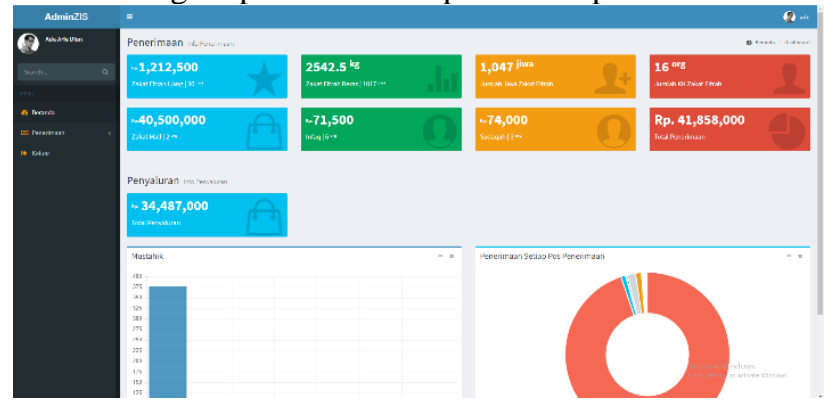

Gambar 7. Antarmuka Halaman Menu Beranda

\section{F. Antarmuka Bagian Pendataan}

Hasil perancangan antarmuka aplikasi salah satunya adalah antarmuka bagian pendataan. Terdiri menu yaitu Beranda dan pendataan.

Beranda merupakan menu utama setelah pengguna berhasil login. Pada halaman ini ditampilkan informasi seperti antar muka administrator. Tampilan halaman Beranda bagian pendataan dapat dilihat pada Gambar 8 .

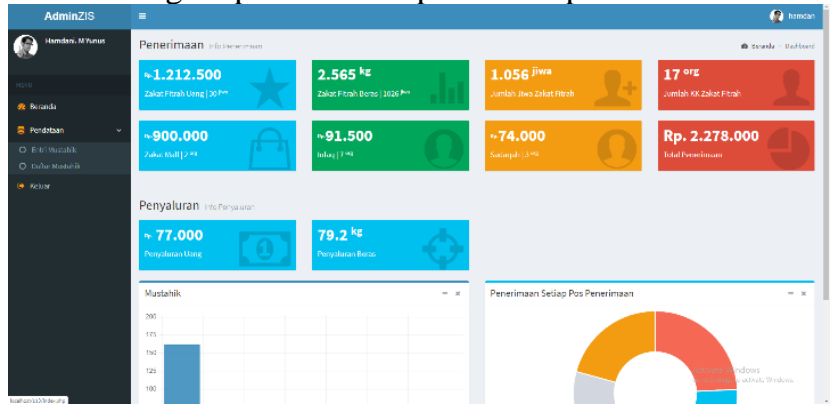

Gambar 8. Antarmuka Halaman Menu Beranda

\section{G. Antarmuka Bagian Penyaluran}

Hasil perancangan antarmuka aplikasi salah satunya adalah antarmuka bagian penyaluran. Terdiri beberapa menu yaitu Beranda dan penyaluran.

Beranda merupakan menu utama setelah pengguna berhasil login. Pada halaman ini ditampilkan informasi seperti antar muka administrator. Tampilan halaman menu Beranda bagian penyaluran dapat dilihat pada Gambar 9 .

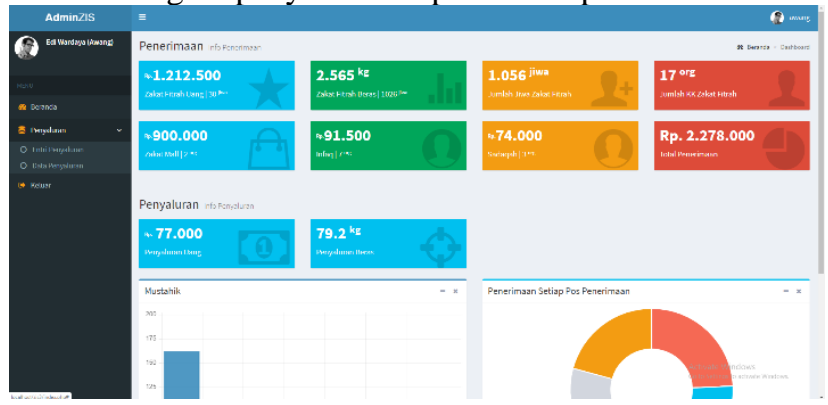

Gambar 9. Antarmuka Halaman Menu Beranda

\section{H. Pengujian}

Pada penelitian dilakukan dua jenis pengujian yaitu pengujian black box dan pengujian use accepting testing (UAT).

\section{Pengujian Black Box}

Black Box pada perangkat lunak dilakukan untuk menguji kesesuaian antara masukan dengan hasil yang ditampilkan pada aplikasi. Pengujian ini berfokus pada spesifikasi fungsional dari software, menguji kondisi input program berdasarkan apa yang dilihat, hanya fokus terhadap fungsionalitas dan output. Pengujian ini perlu dilakukan untuk melihat respon yang diberikan oleh aplikasi saat melakukan proses input data. Pengujian input data dilakukan pada data login, input master data, input penerimaan, input data mustahik, dan input penyaluran.

a) Pengujian Login

Pengujian input data dilakukan pada halaman login. Input data yang diuji adalah saat memasukkan username dan password. Lihat Tabel 1. 
TABEL I

PENGUJIAN HASIL UJI INPUT LOGIN

\begin{tabular}{|c|l|l|l|}
\hline \multicolumn{2}{|c|}{$\begin{array}{l}\text { Skenario } \\
\text { Pengujian }\end{array}$} & \multicolumn{1}{c|}{$\begin{array}{c}\text { Hasil } \\
\text { Uji }\end{array}$} & $\begin{array}{l}\text { Hasil Yang Diharapkan } \\
\text { (Keterangan) }\end{array}$ \\
\hline 1 & $\begin{array}{l}\text { Input data } \\
\text { kosong }\end{array}$ & Tidak Berhasil & $\begin{array}{l}\text { Tidak dapat masuk ke } \\
\text { aplikasi dan menampilkan } \\
\text { pesan:"harap isi bidang ini". }\end{array}$ \\
\hline 2 & $\begin{array}{l}\text { Input data } \\
\text { salah satu } \\
\text { kosong }\end{array}$ & Tidak Berhasil & $\begin{array}{l}\text { Tidak dapat masuk ke } \\
\text { aplikasi, dan menampilkan } \\
\text { pesan kesalahan: } \\
\text { "harap isi bidang ini" }\end{array}$ \\
\hline 3 & $\begin{array}{l}\text { Input } \\
\text { username dan } \\
\text { atau } \\
\text { password } \\
\text { tidak benar }\end{array}$ & Tidak Berhasil & $\begin{array}{l}\text { Aplikasi akan menolak jika } \\
\text { disimpan, dan menampilkan } \\
\text { pesan kesalahan: } \\
\text { "pastikan username dan } \\
\text { password anda benar" }\end{array}$ \\
\hline 4 & $\begin{array}{l}\text { Input } \\
\text { username dan } \\
\text { atau } \\
\text { password } \\
\text { benar }\end{array}$ & Berhasil & $\begin{array}{l}\text { Berhasil login dan masuk ke } \\
\text { aplikasi }\end{array}$ \\
\hline
\end{tabular}

b) Pengujian Manajemen Data

Pengujian input data dilakukan pada halaman super administrator dan administrator. Input data yang diuji adalah saat memasukkan data lembaga, pengelola, users, pos penerimaan, wilayah pendataan dan hitung penyaluran asnab. Proses pengujian data lainnya juga dilakukan sama dan menghasilkan perilaku aplikasi yang juga sama. Lihat Tabel 2 .

TABEL II

PENGUJIAN HASIL UJI INPUT MASTER DATA

\begin{tabular}{|c|l|l|l|}
\hline \multicolumn{2}{|c|}{$\begin{array}{c}\text { Skenario } \\
\text { Pengujian }\end{array}$} & $\begin{array}{c}\text { Hasil } \\
\text { Uji }\end{array}$ & \multicolumn{1}{c|}{$\begin{array}{c}\text { Hasil Yang Diharapkan } \\
\text { (Keterangan) }\end{array}$} \\
\hline 1 & $\begin{array}{l}\text { Input data } \\
\text { kosong }\end{array}$ & $\begin{array}{l}\text { Tidak } \\
\text { Berhasil }\end{array}$ & $\begin{array}{l}\text { Aplikasi akan menolak jika } \\
\text { disimpan, dan menampilkan pesan } \\
\text { kesalahan: } \\
\text { "Harap isi bidang ini" }\end{array}$ \\
\hline 2 & $\begin{array}{l}\text { Input data } \\
\text { salah satu } \\
\text { kosong }\end{array}$ & $\begin{array}{l}\text { Tidak } \\
\text { Berhasil }\end{array}$ & $\begin{array}{l}\text { Tidak berhasil menyimpan dan } \\
\text { menampilkan pesan kesalahan: } \\
\text { "Harap isi bidang ini" }\end{array}$ \\
\hline 3 & $\begin{array}{l}\text { Input } \\
\text { semua data } \\
\text { diisi }\end{array}$ & Berhasil & $\begin{array}{l}\text { Aplikasi akan menyimpan data dan } \\
\text { menampilkan pada tabel. }\end{array}$ \\
\hline
\end{tabular}

c) Pengujian Data Penerimaan

Pengujian dilakukan pada halaman penerimaan oleh bagian penerimaan. Input data yang diuji adalah saat memasukkan penerimaan ZIS disetiap pos penerimaan. Proses pengujian data lainnya juga dilakukan sama dan menghasilkan perilaku aplikasi yang juga sama. Lihat Tabel 3.

TABEL III

PENGUJIAN HASIL UJI INPUT DATA PENERIMAAN

\begin{tabular}{|c|l|l|l|}
\hline \multicolumn{2}{|c|}{$\begin{array}{c}\text { Skenario } \\
\text { Pengujian }\end{array}$} & \multicolumn{1}{|c|}{$\begin{array}{c}\text { Hasil } \\
\text { Uji }\end{array}$} & $\begin{array}{c}\text { Hasil Yang Diharapkan } \\
\text { (Keterangan) }\end{array}$ \\
\hline 1 & $\begin{array}{l}\text { Input data } \\
\text { kosong }\end{array}$ & $\begin{array}{l}\text { Tidak } \\
\text { Berhasil }\end{array}$ & $\begin{array}{l}\text { Aplikasi akan menolak jika } \\
\text { disimpan, dan menampilkan } \\
\text { pesan kesalahan: } \\
\text { "Harap isi bidang ini" }\end{array}$ \\
\hline 2 & $\begin{array}{l}\text { Input } \\
\text { semua } \\
\text { data diisi }\end{array}$ & Berhasil & $\begin{array}{l}\text { Aplikasi akan menyimpan data } \\
\text { dan menampilkan pada tabel. }\end{array}$ \\
\hline
\end{tabular}

d) Pengujian Data Mustahik

Pengujian dilakukan pada halaman pendataan atau halaman mustahik oleh bagian pendataan. Input data yang diuji adalah saat memasukkan data mustahik disetiap wilayah pendataan. Proses pengujian data lainnya juga dilakukan sama dan menghasilkan perilaku aplikasi yang juga sama. Lihat Tabel4.

TABEL IV

PENGUJIAN HASIL UJI INPUT DATA MUSTAHIK

\begin{tabular}{|c|l|l|l|}
\hline \multicolumn{2}{|c|}{$\begin{array}{l}\text { Skenario } \\
\text { Pengujian }\end{array}$} & \multicolumn{1}{|c|}{$\begin{array}{c}\text { Hasil } \\
\text { Uji }\end{array}$} & $\begin{array}{c}\text { Hasil Yang Diharapkan } \\
\text { (Keterangan) }\end{array}$ \\
\hline 1 & $\begin{array}{l}\text { Input data } \\
\text { kosong }\end{array}$ & $\begin{array}{l}\text { Tidak } \\
\text { Berhasil }\end{array}$ & $\begin{array}{l}\text { Aplikasi akan menolak jika } \\
\text { disimpan, dan menampilkan } \\
\text { pesan kesalahan: } \\
\text { "Harap isi bidang ini" }\end{array}$ \\
\hline 2 & $\begin{array}{l}\text { Input } \\
\text { semua data } \\
\text { diisi }\end{array}$ & Berhasil & $\begin{array}{l}\text { Aplikasi akan menyimpan data } \\
\text { dan menampilkan pada tabel. }\end{array}$ \\
\hline
\end{tabular}

e) Pengujian Data Penyaluran

Pengujian input data pemotongan ternak dilakukan pada halaman aplikasi pelaporan bantuan peternakan oleh admin kecamatan dan admin desa. Input data yang diuji adalah saat memasukkan data pemotongan ternak tiap desa dan kecamatan. Proses pengujian data lainnya juga dilakukan sama dan menghasilkan perilaku aplikasi yang juga sama. Lihat Tabel 5 .

TABEL V

PENGUJIAN HASIL UJI INPUT DATA PENYALURAN

\begin{tabular}{|c|l|l|l|}
\hline \multicolumn{2}{|c|}{$\begin{array}{l}\text { Skenario } \\
\text { Pengujian }\end{array}$} & $\begin{array}{c}\text { Hasil } \\
\text { Uji }\end{array}$ & $\begin{array}{l}\text { Hasil Yang Diharapkan } \\
\text { (Keterangan) }\end{array}$ \\
\hline 1 & $\begin{array}{l}\text { Input data cari } \\
\text { mustahik kosong }\end{array}$ & $\begin{array}{l}\text { Tidak } \\
\text { Berhasil }\end{array}$ & $\begin{array}{l}\text { Aplikasi tidak menampilkan } \\
\text { data mustahik dan } \\
\text { menampilkan pesan kesalahan: } \\
\text { "data tidak ditemukan atau } \\
\text { sudah disalurkan" }\end{array}$ \\
\hline 2 & $\begin{array}{l}\text { Input data cari } \\
\text { mustahik diisi } \\
\text { mustahik yang } \\
\text { sudah disalurkan }\end{array}$ & $\begin{array}{l}\text { Tidak } \\
\text { Berhasil }\end{array}$ & $\begin{array}{l}\text { Aplikasi tidak menampilkan } \\
\text { data mustahik dan } \\
\text { menampilkan pesan kesalahan: } \\
\text { "data tidak ditemukan atau } \\
\text { sudah disalurkan" }\end{array}$ \\
\hline 3 & $\begin{array}{l}\text { Input data cari } \\
\text { mustahik diisi } \\
\text { mustahik yang } \\
\text { belum disalurkan }\end{array}$ & Berhasil & $\begin{array}{l}\text { Aplikasi menampilkan data } \\
\text { mustahik pada halaman input } \\
\text { data penyaluran. }\end{array}$ \\
\hline 4 & $\begin{array}{l}\text { Input data } \\
\text { penyaluran } \\
\text { kosong }\end{array}$ & $\begin{array}{l}\text { Tidak } \\
\text { Berhasil }\end{array}$ & $\begin{array}{l}\text { Aplikasi akan menolak jika } \\
\text { disimpan, dan menampilkan } \\
\text { pesan kesalahan: } \\
\text { "Silahkan cari mustahik" }\end{array}$ \\
\hline 5 & $\begin{array}{l}\text { Input } \text { semua } \\
\text { data penyaluran } \\
\text { diisi }\end{array}$ & Berhasil & $\begin{array}{l}\text { Aplikasi akan menyimpan data } \\
\text { dan menampilkan } \\
\text { data pada tabel. }\end{array}$ \\
\hline
\end{tabular}

\section{Hasil Pengujian Daya Terima}

Pengujian dengan daya terima dilakukan dengan mengajukan pertanyaan kepada responden. Perhitungan yang dilakukan berdasarkan hasil pengujian kuesioner terhadap pengelola Zakat, Infaq dan Sadaqah pada Yayasan Al-Fatwa sebagai respondennya. Jumlah responden pada penelitian ini adalah 5 orang yang terdiri dari super administrator, administrator, bagian penerimaan, bagian pendataan, dan bagian penyaluran. Pada setiap 
pengujian yang dilakukan kepada responden terdapat 5 opsi jawaban yang ditawarkan. Jumlah pertanyaan yang diajukan dalam pengujian sistem kepada responden adalah 10 pertanyaan. Hasil perhitungan yang dihitung dengan skala likert's ini dapat dilihat pada tabel 6 dengan perhitungan sebagai berikut :

TABEL VI

HASIL PENGUJIAN DATA TERIMA

\begin{tabular}{|c|c|c|c|c|c|c|c|c|c|c|c|}
\hline \multirow{2}{*}{ RESPONDEN } & \multicolumn{10}{|c|}{ HASIL PENGUJIAN } & \multirow{2}{*}{ TOTAL } \\
\cline { 2 - 11 } & $\mathbf{1}$ & $\mathbf{2}$ & $\mathbf{3}$ & $\mathbf{4}$ & $\mathbf{5}$ & $\mathbf{6}$ & $\mathbf{7}$ & $\mathbf{8}$ & $\mathbf{9}$ & $\mathbf{1 0}$ & \\
\hline 1 & 4 & 4 & 4 & 4 & 4 & 4 & 4 & 4 & 4 & 4 & 40 \\
\hline 2 & 4 & 4 & 3 & 4 & 4 & 4 & 3 & 4 & 4 & 4 & 38 \\
\hline 3 & 4 & 3 & 4 & 4 & 4 & 4 & 4 & 4 & 4 & 3 & 38 \\
\hline 4 & 3 & 4 & 4 & 4 & 3 & 3 & 4 & 3 & 4 & 4 & 36 \\
\hline 5 & 4 & 4 & 3 & 4 & 3 & 4 & 4 & 4 & 4 & 4 & 38 \\
\hline \multicolumn{10}{|c|}{ TOTAL } \\
\hline
\end{tabular}

Berdasarkan user acceptance test, total skor yang diperoleh dari 5 responden dengan 10 item pertanyaan yakni 190. Nilai terdapat diantara median dan kuartil III pada interpretasi LSR, sehingga dapat diketahui bahwa responden menilai aplikasi yang dibuat positif dan cukup berhasil.

\section{KESIMPULAN}

Kesimpulan yang didapat dari hasil metodologi penelitian, analisis, perancangan dan pengujian terhadap aplikasi pengelolaan zakat, infaq dan sadaqah pada Yayasan Al-Fatwa adalah sebagai berikut:

Hasil dari pengujian blackbox, aplikasi berhasil beroperasi dengan baik dan hasil dari pengujian daya terima oleh 5 responden dari 10 pertanyaan, mendapatkan total nilai 190 maka disimpulkan aplikasi dinilai positif atau cukup berhasil dan dapat diterima serta digunakan oleh Yayasan Al-Fatwa.

Aplikasi pengelolaan zakat, infaq dan sadaqah ini berhasil dibangun dan dapat membantu petugas untuk proses penerimaan, pendataan mustahik dan penyaluran. Sehingga aplikasi yang dibangun mampu menggantikan proses pengelolaan zakat, infaq dan sadaqah yang konvensional dimana pada aplikasi ini setiap data yang dimasukkan oleh petugas akan terintegrasi dan dapat mencegah terlambatnya penyaluran zakat, infaq dan sadaqah.

\section{DAFTAR PUSTAKA}

[1] H. Jogiyanto, Analisis dan Desain Sistem Informasi, Yogyakarta: Andi Offset, 2005.

[2] G. Y. Swara dan D. Hakim, "Perancangan Sistem Aplikasi Pengolahan Zakat Berbasis Web (Studi Kasus : Badan Amil Zakat Masjid Raya Andalas Kota Padang)," TEKNOIF, vol. 4, no. 1, 2016.

[3] Amirizal, Sistem Informasi Badan Amil Zakat Berbasis Web (Studi Kasus : BAZ Kota Pekanbaru), Pekanbaru: Fakultas Sains Dan Teknologi Universitas Islam Negeri Sultan Syarif Kasim Riau, 2014.

[4] A. K. Pribadi, B. Waspodo and N. A. Hidayah, "Sistem Informasi Penerimaan dan Penyaluran Zakat dengan Distribusi Konsumtif Dan Produktif," Sistem Informasi, vol. 3, no. 2, 2010.

[5] A. Bakir, Hukum Zakat, Jogjakarta: Lontar Mediatama, 2017.

[6] R. A. Sukamto and M. Shalahuddin, Rekayasa Perangkat Lunak,
Bandung: Informatika, 2013.

[7] A. Kadir, Konsep dan Tuntunan Praktis Basis Data, Yogyakarta: Penerbit Andi, 1998.

[8] A. Kadir, Dasar Pemograman Web Dinamis Menggunakan PHP, Yogyakarta: Andi, 2008.

[9] H. Jogiyanto, Analisis Perancangan Sistem Informasi, Yogyakarta: Andi Offset, 2001.

[10] R. S. Pressman, Rekayasa Perangkat Lunak, Yogyakarta: Andi, 2002.

[11] W. E. Perry, Effective Methods for Software Testing 3rd Edition, Indianapolis, Indiana: Wiley Publishing. Inc, 2006.

[12] Akon and Riduwan, Aplikasi Statistika dan Metode Penelitian untuk Administrasi dan Manajemen, Bandung: Dewa Ruci, 2009. 